JOURNAL OF ENGINEERING SCIENCES

ЖУРНАЛ ІНЖЕНЕРНИХ НАУК

ЖУРНАЛ ИНЖЕНЕРНЫХ НАУК

Web site: http://jes.sumdu.edu.ua

DOI: $10.21272 /$ jes.2019.6(1).h1

Volume 6, Issue 1 (2019)

UDC 504.054:631.46

\author{
Remediation of Soil Contaminated with Heavy Metals \\ Plyatsuk L. D. ${ }^{1}$, Chernysh Y. Y. ${ }^{{ }^{*}}$, Ablieieva I. Y. ${ }^{1}$, Yakhnenko O. M. ${ }^{1}$, \\ Bataltsev E. V. ${ }^{1}$, Balintova M. ${ }^{2}$, Hurets L. L. ${ }^{1}$ \\ ${ }^{1}$ Sumy State University, 2 Rymskogo-Korsakova St., 40007 Sumy, Ukraine; \\ ${ }^{2}$ Technical University of Kosice, 1 Letna St., 04001 Kosice, Slovakia
}

\author{
Article info: \\ Paper received: \\ The final version of the paper received: \\ Paper accepted online: \\ October 13, 2018
February 9, 2019
February 14, 2019
}

*Corresponding Author's Address:

e.chernish@ssu.edu.ua

\begin{abstract}
The paper is focused on the research of the applied aspects of soil remediation, in particular the process of heavy metals (HM) binding and intensifying the cultivation of a soil microbiome using various organic-mineral compositions: biogenic composite, which is the product of anaerobic transformation of sewage sludge and phosphogypsum; organic-mineral compost, based on a mixture of phosphogypsum, superphosphate and cattle humus; and a combination of a mixture of sodium humate and superphosphate. The integration of theoretical and experimental principles in the synergy analysis of the interrelations in the system "object - subject of research" in the study of the dynamics of changes in the forms of HM finding in the soil was carried out. The percentage content of the mobile forms of HM released by the extractant from their gross content before and after the treatment of the soil with organic-mineral compositions was determined with the spectrophotometric method using. The comparison of the soil processing efficiency was determined. Correlation relations of the dynamics in the biomass oxidative ability values for the soil biome and the rate of the substrate oxidation was proved over time treatment with different doses of the biocomposite with using of mathematical statistics methods.
\end{abstract}

Keywords: heavy metals, soil remediation, organic-mineral compositions, phosphogypsum, soil biome, oxidative ability of the biomass.

\section{Introduction}

The growing anthropogenic impact on the ecosystem causes changes in the natural soil-forming process. The dangerous factors of anthropogenic origin are the processes of intensification of heavy metals (HM) migration in the edaphotop, which cause devegetation and dehumidification, destructive changes in the agrophysical, physicochemical and biological properties of the soil, until its toxicity. The soil receives HM by various ways: with the gas-dust emissions from industrial enterprises and vehicles, liquid and solid household waste, with sewage from agricultural enterprises, pesticides, with impurities of organic and mineral fertilizers in particular, etc. They are accumulated in the soil to concentrations that are hazardous for living objects.

$\mathrm{HM}$ fall from the atmosphere into the soil principally in the form of oxides, which gradually dissolve, passing into hydroxides, carbonates or in the form of exchanged cations [1].

It should be noted that heat power takes the first place by the impact value and gross inflow of HM into the atmosphere due to combustion of organic fuel in boiler units (on thermal power stations, boiler houses and in the industrial furnaces). The combustion of coal and fuel oil, which are still dominated it the fuel structure of most countries, is the main source of HM in the atmosphere. The coal contains almost all known heavy metals. One ton of carbon soot can contain maximum $10 \mathrm{~kg}$ of $\mathrm{Sr}, \mathrm{V}$, $\mathrm{Zn}$ and Ge [2].

It is known that the mobility of HM in the system "soil-plant" is largely determined by the physical and chemical properties of soils, by the content of organic matter and the activity of microorganisms that actively participate in the transformation of substances in soils.

The processes of the migration of HM occur or intensify under the impact of the plants root extract that makes the soil aggregates wet, affects the physical and chemical exchange (absorption) capacity of the soil, and binds cations of two- and polyvalent metals with carboxyl and hydroxyl groups of polysaccharides, amino acids and carboxylic acids into complex compounds, and it also concentrates cations, which cause the gradual toxication of soil ecosystems. 
So, the current task for today is the regulating of the buffer properties of soils by improving existing and developing new ways to reduce the mobility of HM in the ecosystem that come from various anthropogenic sources.

\section{Literature Review}

Rehabilitation of soils contaminated with heavy metals is usually based on the use of such meliorants as lime, gypsum, as well as phosphates and organic matter of different genesis.

The use of lime is more effective on soils with acid reaction, on high-buffer soils. An increasing $\mathrm{pH}$ to 7.5 and more causes to the formation of compounds of hexavalent chromium, which are very mobile, toxic and not sorbtive. Besides, lime and phosphorus-containing compounds reduce the arrival of toxic metals into the plant, complicate absorption of metabolites $(\mathrm{Cu}, \mathrm{Zn}, \mathrm{Mn})$, creating their shortage and reducing crop's productivity $[3,4]$.

The use of natural sorbents is advantageous because they are affordable, cheap and environmentally friendly. At the same time, not all is clear about their role as an inactivators of $\mathrm{HM}$ in the soil [5].

The introduction of organic fertilizers is a method that reduces the mobility of lead in the soil and reduces its entry into plants, but it is unclear how long this immobilization effect will be shown, because organic fertilizers are eventually mineralized, which also affects the mobility of lead in the soil [6].

The importance of liming as a method of soil melioration is well known and well-studied for turf-podzolic soils. However, liming cannot be considered only as a way of eliminating the soil acidity, because acidic soils have a complex of adverse properties. Physical and physical-chemical properties of soils are improved during the liming, the density decreases significantly, the filtration and aeration increases, the mechanical resistance is reduced, the cation exchange capacity increases, the composition of the soil absorption complex changes.

Liming affects the use of nutrients from soil and fertilizers by plants. It influence is significant on soil microflora. Besides, the ability of the roots to absorb a number of HM, in particular lead, decreases as a result of increasing Ca. Liming also contributes to the formation of complexes of organic substances of soil with HM, which reduces the mobility of $\mathrm{Hg}, \mathrm{Cd}, \mathrm{Zn}, \mathrm{Cu}, \mathrm{Ni}, \mathrm{Cr}$ [7-9].

A recent analysis [10] showed that many types of materials such as lime, metal oxides, phosphate compounds, organic matter, calcium carbonate, red mud, bone meal, and fly ash may be used to the media for soil amendments.

The results obtained by [11] suggest phosphate compounds enhance the immobilization of metal(loid)s such as $\mathrm{Cd}, \mathrm{Pb}$, and $\mathrm{Zn}$ in soils through various processes. Rock phosphate reduced $\mathrm{Pb}, \mathrm{Cd}$, and $\mathrm{Zn}$ by $99.9-24.0 \%$, DAP reduced $\mathrm{Cd}$ and $\mathrm{Zn}$ by more than $77 \%$ and $91 \%$ for $\mathrm{Cd}$ [12]. The $\mathrm{P}$ application is considered an attractive technology for managing metal(loid)-contaminated soils, however the large-scale use of $\mathrm{P}$ compounds can contaminate surface and groundwater, future research should aim to develop the remediation method with the minimum impact of $\mathrm{P}$ on quality of water sources.

According to [13] strongest reductions occurred after cyclonic ashes $(\mathrm{CA})+$ steel shots $(\mathrm{SS})$ and compost $(\mathrm{C})+$ + cyclonic ashes $(\mathrm{CA})+$ steel shots (SS) treatments (99-97\% for $\mathrm{Cd}$ and $\mathrm{Zn}$ ), while $\mathrm{Pb}$ and $\mathrm{Cu}$ leaching increased after $\mathrm{C}$ and $\mathrm{C}+\mathrm{CA}$ treatment $(3.3-17.0 \%$, respectively). Noteworthy, if too many $\mathrm{OM}$ is added into soil, nutrition can be released at the short time, an outflow of them into the groundwater and subsequently make water polluted. In addition, the incorporation of $\mathrm{OM}$ in soil can be time consuming.

Xie Y. et al. [14] analyzed the effectiveness of six amendments (composed with bentonite, phosphate, humic acid, biochar, sepiolite powder, biological matrix, silicon fertilizer on the for remediating cadmium and copper co-contaminated soil and reducing the metal concentration in Rhizoma Chuanxiong. The disadvantage of the method is that the maximum possible efficiency of the extraction of heavy metals such as $\mathrm{Cd}, \mathrm{Cu}, \mathrm{Pd}$ and $\mathrm{Zn}$ with the use of compositions with different compositions is revealed, which does not allow to unify the application of the method.

There is a method [15] for the remediation of the soil technogenically contaminated with heavy metals, it includes a one-time treatment of soil with a combination of a mixture of sodium humate with superphosphate, lime or organic matter in accordance with the soil. Sodium humate, superphosphate and lime are used for soil containing $\mathrm{Cd}$, Cr. Sodium humate, superphosphate and manure are used for soil containing $\mathrm{Zn}$.

The disadvantages of this method are the lack of a unified approach to the treatment of soils with a different combination of heavy metals, that limits its use. Besides, the influence of the $\mathrm{pH}$ of the soil environment, which affects the mobility of heavy metals and the efficiency of their binding in the low soluble compounds, was not taken into account.

There is a method [16] for purifying chernozem soils contaminated with heavy metals, which includes the use of an inducing agent. Organic-mineral compost is used as such a substance, it is prepared by mixing phosphogypsum, simple superphosphate and cattle's humus. Compost is introduced into the soil once for 4-5 years at a dose of 100-110 tons/hectare with an organic content in it up to $20 \%$ and $\mathrm{pH}$ of $6.0-6.5$. This contributes to lowering the alkalinity of chernozem soils to $\mathrm{pH} 7.2-7.8$, then it is laid by a cultivator to a depth of $20-25 \mathrm{~cm}$.

The main disadvantage of this method is the lack of technological conditions that ensure the detoxification of organic and mineral waste during their composting. So, harmful impurities may be in sewage sludge and phosphogypsum. It is heavy metals, which are in exchange form during composting and may subsequently be available to plants when such compost is introduced to soil.

A well-known method [17] describes the technical solution "Washing of contaminated soils", aimed at the purification and recovery of soils and sediments contaminated with HM, using a detergent solution with chelating agents. 
The chelating agent forms water-soluble complexes with metals and in this way facilitates removal of the metal from soils and sediments into the washing solution. This method involves the separation of the solid phase of the soil and sediment, and the rinsing solution used in the filter press chamber and the rinsing of the solid phase to remove all residual mobilized contaminants at the same time. The recycle of chelating agents and process water in a closed process circuit is provided by applying a $\mathrm{pH}$ gradient and using advanced oxidation processes for treatment of process water.

The disadvantages of this method include the complexity of the implementation process, the need for mechanical removal of soil contaminated with heavy metals in order to further treatment it in a known way, the high energy consumption of the treatment process, the use of expensive chelating agents and the generation of secondary waste requiring disposal or destruction.

There is a method [18] for purifying clay soils and sludge, which includes removing radionuclides and heavy metals by treating slimes and soils with a chemical reagent. An aqueous solution of epy di- or triammonium salt of ethylenediaminetetraacetic acid (EDTA) with a concentration of $0.01-0.05 \mathrm{~mol} / \mathrm{dm}^{3}$ is used as a reagent.

But this method can be used on soils containing HM, capable of forming stable complex compounds with EDTA, and with high content of clay components (14$20 \%$ ). Similarly, chelate-assisted remediation of HM can also cause off-site movement of HM [19]. During EDTAassisted solubilization of HM, plants can absorb only a limited fraction of mobilized metal and the remaining amount of HM are generally leached down [20]. Therefore, it is highly necessary that application of chelating agents is limited to their lowest level for ecological and economic benefits.

Improvement of compositions and the creation of new organo-mineral complexes for regulating the soil buffer properties that allow the regulation of mobility of HM are actual. It may help to eliminate or at least reduce the harmful effects of excessive amount of HM on the biotic constituent of ecosystems and edafopops.

The paper is focused on the research of the applied aspects of soil remediation, in particular the process of heavy metals (HM) binding and intensifying the cultivation of a soil microbiome, using various organic-mineral compositions.

To achieve the aim, the following tasks were set:

- research of the binding process of heavy metals in the soil under the various organic-mineral compositions action;

- comparison of different approaches to the determination of the metabolic activity of microorganisms in soil microzones under the stimulating effect of the biogenic composite as a product of anaerobic treatment of sewage sludge and phosphogypsum.

\section{Research Methodology}

\subsection{The theoretical foundations of the work}

For the formation of a general research concept the synergism of the object and subject of research should be considered. The object of the research can be represented as the impact of heavy metals on the soil ecosystem. At the same time such an impact can lead to the passage of the ecosystem through the bifurcation point when the boundary condition is reached (for example, the maximum bioaccumulation values of the pollutant in the natural components) even with minor fluctuations of the system parameters. This brings the ecosystem to a new development level, in our case - to degradation and increasing instability. A general scheme for combining scientific-theoretical and experimental researches (Figure 1) was formed in the context of developing an integrated methodological approach to the process of studying biotechnological techniques for soil remediation. In particular, the main direction is the formation of the biochemical basis of the research organization to find out how organic-mineral compositions effect on the process of binding heavy metals and the microbial biome oxidative ability of the soil.

The subject of research can be characterized as a process aimed at reducing the negative impact by introducing organic-mineral compositions for binding heavy metals, which through ecosystem autocatalysis can increase its degree of stability and intensify the development process of the soil biome and the humification process directly associated with the rate of productive substrate oxidation.

\subsection{Conditions of the microfield experiment}

Research of quantitative and qualitative changes in the fractional composition of the soil complex of gray forest soil was carried out with increasing doses of organicmineral complexes.

The experiment carried out in blocks of organic glass with perforated bottom with a surface area $0.2 \mathrm{~m}^{2}$. Blocks were filled with gray forest soil from a territory with a high level of anthropogenic impact, containing lead at levels of $17.6-21.2 \mathrm{mg} / \mathrm{kg}$ and cadmium - 0.55$1.00 \mathrm{mg} / \mathrm{kg}$ (gross shape). The indoor temperature was maintained at the level of $22-25{ }^{\circ} \mathrm{C}$.

Ammonia-acetate buffer solution with a $\mathrm{pH} 4.8$ was used to prepare the extract from air-dry soil samples. This extractant is accepted by the agrochemical service for the extraction of microelements available to plants and serves to assess the soils nutrition with these elements. The obtained solutions were analyzed on a spectrophotometer "C115-M1" (OJSC "SELMI", Ukraine) with an electrothermal atomizer.

Statistical processing of the results was carried out in MS EXEL. The percentage content of the HM mobile forms released by the extracting from their gross content before and after the treatment of the soil by organicmineral compositions was determined. 


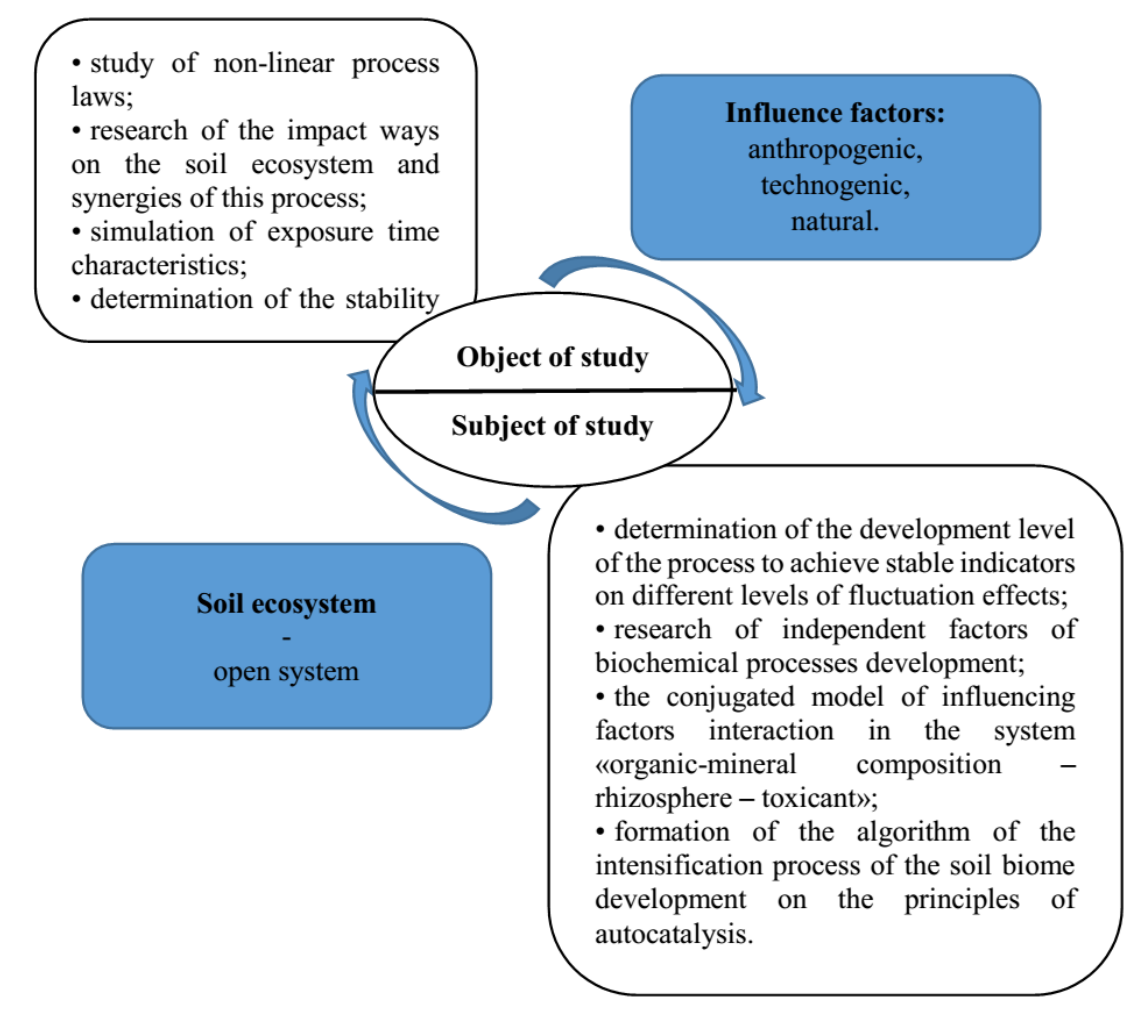

Figure 1 - Block diagram of the integration of theoretical and experimental research in the framework of interrelations in the system «object-subject» of the research

Then the degree of decrease in the heavy metals mobility in the soil was determined by adding various organic-mineral composites according to the formula:

$$
D_{H M}=\frac{b_{0}-b_{1}}{b_{0}} \cdot 100 \%,
$$

where $D_{H M}$ - degree of decrease of heavy metals mobility in the soil, $\% ; b_{0}$ - initial percentage content of moving forms of $\mathrm{HM}, \%$; $\mathrm{b}_{1}$ - percentage of moving $\mathrm{HM}$ forms after processing, $\%$.

The effect of different doses of the biocomposite on the soil biome can be estimated by the change in the kinetic parameters of the development of rhizosphere microorganisms, in particular, by the accumulation of microbial biomass.

The method for the determination of microbial carbon in the soil is based on the respiratory response of microorganisms to the introduction of glucose $(10 \mathrm{~g}$ of soil was mixed with glucose at a proportion of $10 \mathrm{mgC} / \mathrm{g}$ ) [21]. The biocomposite, after anaerobic treatment, has a high level of mineralization of sewage sludge with a biotransformed phosphogypsum as mineral base. Therefore, it was decided to apply this method. It should be noted that this method is not recommended for use in soils enriched with fresh decomposed organic matter (straw, manure, etc.).

According to the X-ray diffractometric analysis [22], the mineral spectrum of the biocomposite revealed the following compounds: quartz, gypsum, potassium hydrogen phosphate hydrate, ammonium sulfate, calcium car- bonate, calcium aluminum sulfate and complex sulfide fraction.

The optimal biocomposite concentrations are determined experimentally in the range $2.5-7.5 \mathrm{~kg} / \mathrm{m}^{2}$.

In this case, microbial biomass can be recalculated according to the formula [21]:

$$
C_{\text {micro }}=30.0 \cdot 10^{-3} \mathrm{~cm}^{3} \mathrm{CO}_{2}-\mathrm{C} / \mathrm{g}^{-1} \cdot \mathrm{h}^{-1} \text {. }
$$

The determination of organic carbon is carried out using the Tyurin method, which is based on the decomposition of organic matter with potassium bichromate in an acidic medium, according to existing methods [23].

The initial period of incubation is characterized by increased $\mathrm{CO}_{2}$ emissions due to the redistribution of nutrients in the soils microzones with mixing, separated from the period of determination (from 0 to 5 hours). So, the calculation of average values was chosen in a 25 -hour interval with a relatively constant rate of $\mathrm{CO}_{2}$.

\section{Results and Discussion}

\subsection{Research of the influence of various organic-mineral compositions on moving forms of heavy metals}

Figure 2 shows the characteristic of the influence of various organic-mineral compositions on the reduction degree of HM mobile forms in the soil (gray forest soils) with an exposure duration is 2 months. 


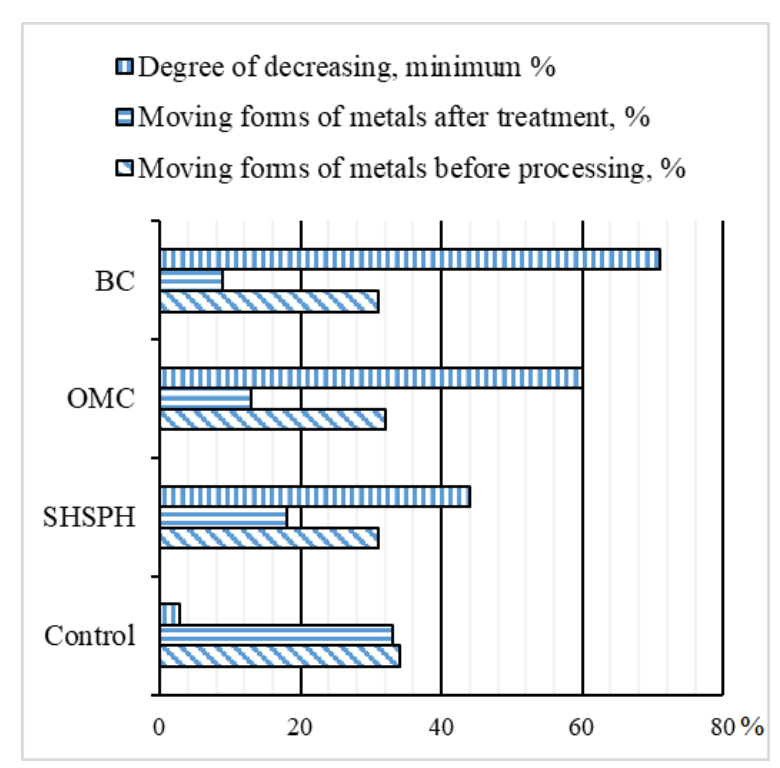

Figure 2 - Comparative characteristics of the influence of various organic-mineral complexes on the binding process of heavy metals moving forms $(\mathrm{Pb}, \mathrm{Cd})$ : $\mathrm{BC}$ is biogenic composite, product of anaerobic processing of the sludge sediments and phosphogypsum; OMC is organic-mineral compost based on a mixture of phosphogypsum (10\% by weight), superphosphate ( $1 \%$ by weight) and cattle humus; SHSPH is a combination of a mixture of sodium humate and superphosphate (1:1)

When organic-mineral compost (OMC) is introduced on the basis of the mixture of phosphogypsum, superphosphate and manure, a decrease in the volume of HM mobile forms by $12 \%$ of the metals total content was determined under the degree of reduction of HM mobile forms was achieved $60 \%$, which is 1.3 times higher than this indicator compared with tillage using a combination of a mixture of sodium humate with superphosphate (SHSPH). There was determined that a more rational content of OMC composition. But exactly the combination HM with humic acids is considered a very effective way of their immobilization when the mineral component of the soil is involved. However, the artificial introduction of humates into the soil in a certain composition does not always determine the high efficiency of the binding of HM into the forms that are not available for migration, which indicates the need for additional research and rationalization of relations in the composition of sodium humate and superphosphate mixture according to biochemical and physical-chemical soil conditions. Industrial humates show a stimulating effect on plant growth, but depending on the production technology and materials they demonstrates a certain level of toxic effects in relatively high doses, which should also be taken into account, because the chemical structure and properties of natural and industrial humates are different. That affects their ecological functions in the soil complex.

There is a higher degree of decrease in HM mobility (at least $70 \%$ ) compared with other organomineral complexes under introducing biogenic composite, which is the product of anaerobic sludge and phosphogypsum processing. It should be noted that the main characteris- tics of the biogenic composite were studied in previous works $[22,24]$ with the reasoning of certain theoretical positions of biochemical influence of biogenic composite on the soil complex.

Thus, it is important to determine the correlation of the changes dynamics in kinetic quantities that characterize the effect of different doses of biogenic composite on the soil biome and the rate of the substrate oxidation over time using mathematical statistics methods.

\subsection{Investigation of the comparison different approach for biomass oxidative capacity in the soil microzones}

Soil respiration in an ecosystem is often used in complex studies of the level of environmental pollution by HM. Analysis of changes in the intensity of soil respiration, measured in situ, in several pollution gradients formed by large point sources of pollutant emission is used as a rapid method to assess the state of the ecosystem. Evaluate soil respiration by the rate of productive oxidation of the substrate by soil microorganisms, according to the release of carbon dioxide.

By approximating the experimental values, one can determine the rate of carbon dioxide $\left(\mathrm{C}-\mathrm{CO}_{2}\right)$ emission in the soil ecosystem by the equation [25]:

$$
v=v_{0}^{p r} \cdot \exp \left(\mu_{m} \cdot \tau\right)+v_{0}^{0},
$$

where $v_{0}^{p r}$ is the initial rate of productive oxidation of the substrate, $\mathrm{mg} /\left(\mathrm{cm}^{3} \cdot \mathrm{h}\right) ; v_{0}{ }^{0}$ - initial velocity of the idle oxidation of the substrate to carbon $\mathrm{CO}_{2}, \mathrm{mg} /\left(\mathrm{cm}^{3} \cdot \mathrm{h}\right)$; $\mu_{\mathrm{m}}-$ maximum specific growth rate of microorganisms, $\mathrm{h}^{-1} ; \tau$ - time, h.

Equation (2) can provide an opportunity to assess the effect of a biocomposite on the metabolic activity of microorganisms in the rhizosphere zone, which play an important role in soil recovery under the biochemical binding of toxic substances, in particular heavy metals.

In the previous work [24] mathematically determined the biomass oxidative ability (BOA) of the soil biome, which determines the protective mechanisms of the soil complex in a consistent transformation with a biocomposite under the process of the interaction in the system "biotic component - biogenic product - toxicant". Thus, with the initial condition $\tau=0$ we have got the equation:

$$
\frac{k_{f}}{1+\frac{k_{f}}{k_{d}}+\frac{k_{f}}{k_{a} \cdot S_{\text {org }} \cdot Y_{\text {bio }}}} \cdot \tau=B O A, \frac{g}{\mathrm{~cm}^{3}} h
$$

where $S_{\text {org }}$ - total organic substrate, including the organic component of the biocomposite, $\mathrm{g} / \mathrm{cm}^{3}$; $\mathrm{Y}_{\text {bio }}-\mathrm{eco}-$ nomic coefficient of biomass output for an additional substrate - biocomposite; $k_{f}$ - the constant of biochemical binding or fixation of metals in the organic-mineral structure; $\mathrm{k}_{\mathrm{d}}$ is dissociation constant; $k_{a}$ - aggregation constant (Table 1).

The obtained mathematical mapping of BOA of the soil biome can be compared with the magnitude of the 
substrate oxidation rate by the soil microbial biomass with the release of $\mathrm{CO}_{2}$ according to the equation (2) and experimental data (Table 2).

Table 1 - Values of the parameters that determine the biomass oxidative ability (BOA)

\begin{tabular}{|c|c|c|}
\hline Indicator & Unit of measurement & Value \\
\hline$k f$ & - & 0.078 \\
\hline$k_{d}$ & - & 0.013 \\
\hline$k_{a}$ & - & 0.344 \\
\hline $\begin{array}{c}Y_{\text {bio }} \\
\text { with a dose } \\
\text { of biocomposite: }\end{array}$ & - & - \\
\hline 2.5 & - & 1.23 \\
\hline 5.0 & - & 2.45 \\
\hline 7.5 & - & 2.56 \\
\hline$S_{\text {org }}$ & $\mathrm{g} / \mathrm{cm}^{3}$ & $7.50-14.80$ \\
\hline
\end{tabular}

The growth rate of microorganisms from equation (2) in its essence can characterize the rate of biomass development, which is taken into account in dependence (3) with used economic biomass yield coefficient under an additional substrate, the biocomposite. This feature can be used to assess the process of stimulating the development of the necessary ecological-trophic groups of microorganisms. Accordingly, it is important to trace the presence of a correlation relationship between the rate of substrate oxidation by the soil microbial biomass with the release of $\mathrm{CO}_{2}$ according to equation (2) and the dynamics of changes in the forms of HM compounds of the soil biome (equation (3)) depending on the biocomposite dose applied to the soil. It should be noted, that both of these indicators can characterize soil respiration and their comparison will allow us to assess the reliability of the mathematical dependence that was obtained in [24].

Table 2 - Experimental data

\begin{tabular}{|c|c|c|c|}
\hline $\begin{array}{c}\text { Sampling } \\
\text { zone }\end{array}$ & $\begin{array}{c}\text { Dose of } \\
\text { biocomposite, } \\
\mathrm{kg} / \mathrm{m}^{2}\end{array}$ & $\begin{array}{c}\text { Maximum } \\
\text { specific growth } \\
\text { rate of micro- } \\
\text { organisms } \\
\mu_{\mathrm{m}} \mathrm{h}^{-1}\end{array}$ & $\begin{array}{c}\text { Microbial } \\
\text { biomass, } \\
\mu \mathrm{gC} / \mathrm{g}\end{array}$ \\
\hline $\begin{array}{c}\text { The soil } \\
\text { of the }\end{array}$ & 2.5 & $0.254 \pm 0.002$ & $192 \pm 3$ \\
rhizosphere & & $0.234 \pm 0.002$ & $188 \pm 5$ \\
The soil & & $0.246 \pm 0.005$ & $183 \pm 2$ \\
$\begin{array}{c}\text { of the } \\
\text { rhizosphere }\end{array}$ & 5.0 & $0.311 \pm 0.002$ & $253 \pm 3$ \\
\hline $\begin{array}{c}\text { The soil } \\
\text { of the }\end{array}$ & 7.5 & $0.317 \pm 0.003$ & $274 \pm 2$ \\
rhizosphere & & $0.312 \pm 0.002$ & $269 \pm 4$ \\
\hline
\end{tabular}

BOA directly takes into account the processes of HM transformation, which can be effectively used for the environmental assessment of the edaphotops conditions during the implementation of remediation measures as a separate indicator of the effectors effect.

Figure 2 shows the comparative dynamics of changes in the values of the biomass oxidative ability (BOA) of the soil biome and the rate of the substrate oxidation ( $v$ ) over time when various doses of the biocomposite with the appropriate determination coefficients are applied.

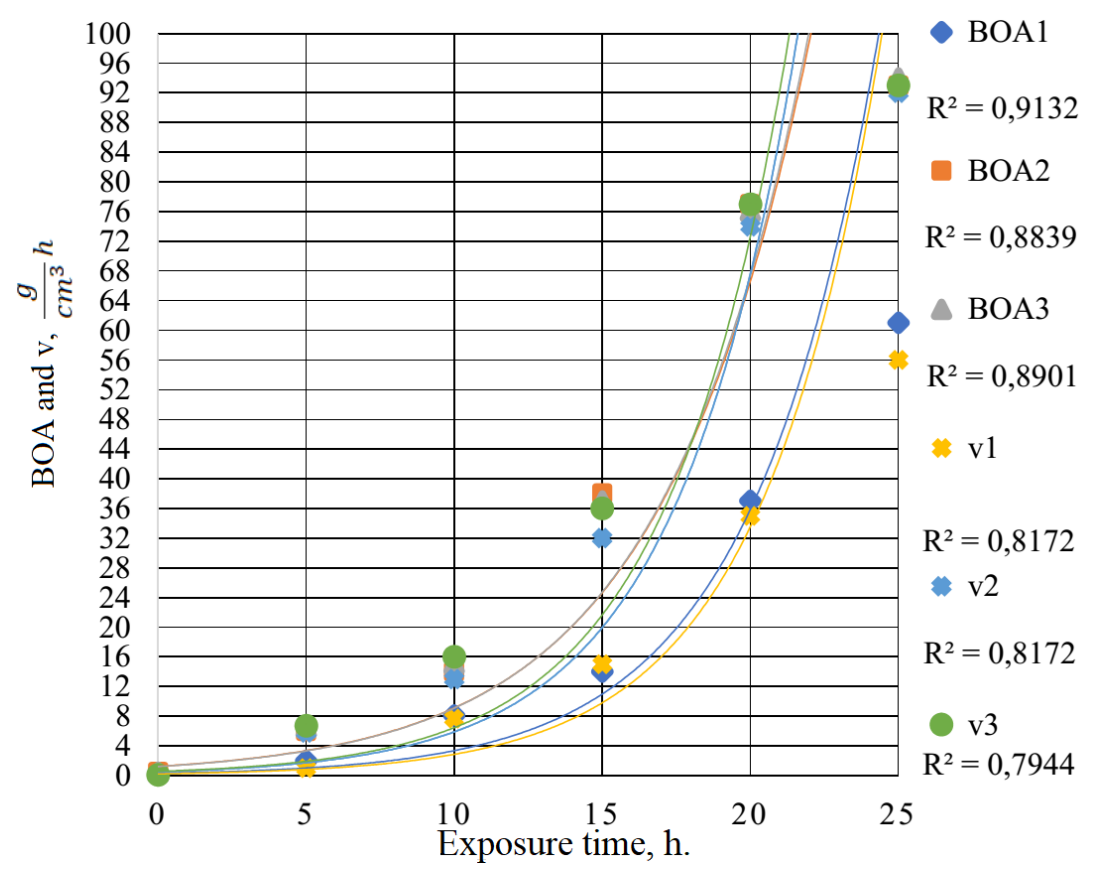

Figure 3 - Comparison of changes in the biomass oxidative ability (BOA) of the soil biome and the rate of the substrate oxidation with the release of carbon dioxide $(v)$ over time when different doses of biocomposite are applied: BOA 1 and $v 1-$ with a dose of biocomposite $2.5 \mathrm{~kg} / \mathrm{cm}^{2}$; BOA2 and $v 2$ - with a dose of biocomposite $5.0 \mathrm{~kg} / \mathrm{cm}^{2}$;

BOA3 and $v 3$ - with a dose of biocomposite $7.5 \mathrm{~kg} / \mathrm{cm}^{2}$ 
Thus, the obtained mathematical expression of the BOA (3) agrees well with the experimental data and their standard mathematical processing. At the same time, it allows to describe the soil respiration and the effect of biocomposite on this process as a result of the leveling of the heavy metals toxic action on the microbial biome (described by the values of the constants $\mathrm{k}_{\phi}, \mathrm{k}_{\mathrm{d}}, \mathrm{k}_{\mathrm{a}}$ ) and stimulation of the development of soil microorganisms of the rhizosphere zone $\left(\mathrm{Y}_{\mathrm{bio}}\right)$ knowing only the total content of organic matter in the soil.

\section{Conclusions}

The maximum degree of reduction in the heavy metals mobility (not less than $70 \%$ ) was achieved in the case of the biogenic composite use based on the research of the influence on the HM moving forms of such organicmineral compositions as a biogenic composite - a product of anaerobic conversion of sludge sediments and phosphogypsum, organic-mineral compost based on a mixture of phosphogypsum (10\% by weight), superphosphate ( $1 \%$ by weight) and manure, and a combination of a mixture of sodium humate with superphosphate $(1: 1)$.

The experimental data was obtained regarding the velocity magnitude of the substrate oxidation by the soil microbial biomass with the release of $\mathrm{CO}_{2}$, by the values of which the growth rate of microorganisms was determined. Correlation relations of the dynamics in BOA values for the soil biome and the rate of the substrate oxidation was proved over time treatment with different doses of the biocomposite with using mathematical statistics methods.

The development of methodical principles for the rapid assessment of the ecological characteristics of the soils of natural and human-made landscapes will be developed in further research under rationalizing the biocomposite dosage on different types of soils.

\section{References}

1. Panchenko, T., Pradivlyana, A., \& Ursul, O. (2018). Estimation of the influence of thermal energy objects on the environment. Materialy XLVII Naukovo-Tekhnichnoyi Konferentsiyi Pidrozdiliv VNTU, Vinnytsya, https://conferences.vntu.edu.ua/index.php/ all-fksa/all-fksa-2018/paper/view/4574.

2. Shevchenko, O. (2013). The heavy metals content in the atmospheric air of Kyiv and sources of their receipt. Chasopys kartohrafiyi : zbirnyk naukovykh prats', Vol. 6, pp. 207-216.

3. Bolshakov, V., \& Borisochkina, T. (2002). Reclamation methods of soil contaminated with heavy metals. Pratsi Hruntovoho Instytutu named after V. V. Dokuchayev, No. 56, pp. 122-127.

4. Sharkova, S. (2010). The use of reclamation techniques for growing spring wheat under the technogenesis conditions. Plodorodiye, No. 3, pp. 51-52.

5. Mineyev, V., Kochetavkin, A., \& Nguyen, V. (1989). Using natural zeolites to prevent heavy metals contamination of soil and plants. Agrokhimiya, No. 8, pp. 85-95.

6. Sharkova, S., \& Nadezhkina, Ye. (2008). The ways to improve the quality of grain in the conditions of anthropogenic pollution. Vestnik Rossiyskoy Akademii Sel'skokhozyaystvennykh Nauk, No. 4, pp. 82-84.

7. Ilin, V., Baydina, N., \& Konarbayeva, G. (2000). The content of heavy metals in soils and plants of Novosibirsk. Agrokhimiya, No. 1, pp. 66-73.

8. Barvinskyy, A. (2012). Soil physico-chemical factors of increasing land productivity in Polissya agrolandscapes. Zemleustriy, Kadastr i Monitorynh Zemel, No. 3-4, pp. 66-75.

9. Efremova, S. Y. (2012). Detoxication Receptions Chemically polluted soils. Izv. Penz. Gos. Pedagog. Univ. named after V. G. Belinskiy, No. 29, pp. 379-382.

10. Derakhshan, Z., Myung, N., Jung C., \& Kim, K.-H. (2017). Remediation of soils contaminated with heavy metals with an emphasis on immobilization technology. Environmental Geochemistry and Health, doi: 10.1007/s10653-017-9964-z.

11. Chen, Y. H., \& Li, F. A. (2010). Kinetic study on removal of copper (II) using goethite and hematite nano-photocatalysts. Journal of Colloid and Interface Science, Vol. 347(2), pp. 277-281.

12. Basta, N., \& McGowen, S. (2004). Evaluation of chemical immobilization treatments for reducing heavy metal transport in a smelter-contaminated soil. Environmental Pollution, Vol. 127(1), pp. 73-82.

13. Ruttens, A., Colpaert, J., Mench, M., Boisson, J., Carleer, R., \& Vangronsveld, J. (2006). Phytostabilization of a metal contaminated sandy soil. Part II. Influence of compost and/or inorganic metal immobilizing soil amendments on metal leaching. Environmental Pollution, Vol. 144(2), pp. 533-539.

14. Xie, Y., Xiao, K, Sun, Y, Gao, Y, Yang, H, \& Xu, H. (2018). Effects of amendments on heavy metal immobilization and uptake by Rhizoma chuanxiong on copper and cadmium contaminated soil. R. Soc. Open Ssci., Vol. 5, 181138, doi: 10.1098/rsos. 181138.

15. Patent of UA for utility model No. 85002. Method of remediation technogenically contaminated with heavy metals of soil. Published on 11.11.2013. Retrieved from http://uapatents.com/7-85002-sposib-remediaci-tekhnogenno-zabrudnenogo-vazhkimimetalami-runtu.html.

16. Patent of RF for utility model No. 2492944. Method of cleaning black soil contaminated with heavy metals. Published on 20.09.2013. Retrieved from http://www.freepatent.ru/patents/2492944.

17. Patent of USA for utility model No. 9108233. Washing of contaminated soils. Published on 18.08.2015. 
18. Patent of UA for utility model No. 82303. A method for cleaning clay-based soils and slurries. Published on 25.03.2008.

19. Shahid, M., Xiong, T., Masood, N., Leveque, T., Quenea, K., Austruy, A., Foucault, Y., \& Dumat, C. (2014). Influence of plant species and phosphorus amendments on metal speciation and bioavailability in a smelter impacted soil: a case study of foodchain contamination. J. Soil. Sediment, Vol. 14, pp. 655-665.

20. Saifullah, Shahid, M., Zia-Ur-Rehman, M., Sabir, M., \& Ahmad, H.R., (2015). Phytoremediation of Pb-contaminated soils using synthetic chelates. Soil Remediation and Plants. Elsevier Inc.

21. Edelgard, Kaiser, Torsten, Müller, Rainer, Georg, Joergensen, \& Heinemeyer, O. (1992). Evaluation of methods to estimate the soil microbial biomass and the relationship with soil texture and organic matter. Soil Biology and Biochemistry. Vol. 24(7), 675683, doi: 10.1016/0038-0717(92)90046-Z.

22. Chernysh, Y. Y., \& Plyatsuk, L. D. (2018). Binding of heavy metals in the soil complex at the introduction biocomposite based on sewage sludge and phosphogypsum. Young Scientist, No. 1(53), pp. 446-450.

23. Derzhspozhyvstandart Ukrayiny (2016). The quality of the soil. Determination of humus group composition by Tyurin method in modification of Konov and Belchikova : DSTU 7855:2015. Kyiv, Ukraine.

24. Chernysh, Ye., \& Plyatsuk, L. (2017). Modeling of the process of stimulation the protective functions of the soil complex using a biogenic composite based on technogen waste. Ecological science, No. 1-2 (16-17), pp. 129-140.

25. Panikov, N. S. (1992). Growth kinetics of microorganisms: general patterns and environmental applications. Science, Moscow.

\title{
Remediation of Soil Contaminated with Heavy Metals
}

\author{
Пляцук Л. Д. ${ }^{1}$, Черниш $€$. Ю. ${ }^{1}$, Аблєєва I. Ю. ${ }^{1}$, Яхненко О. М. ${ }^{1}$, \\ Батальцев Є. В. ${ }^{1}$, Балінтова М. ${ }^{2}$, Гурець Л. Л. ${ }^{1}$ \\ ${ }^{1}$ Сумський державний університет, вул. Римського-Корсакова, 2, 40007, м. Суми, Україна; \\ ${ }^{2}$ Технічний університет м. Кошице, вул. Летна, 1, 40001, м. Кошице, Словаччина
}

\begin{abstract}
Анотація. Стаття присвячена дослідженню прикладних аспектів рекультивації грунтів, зокрема процесу зв'язування важких металів та інтенсифікації вирощування грунтового мікробіома 3 використанням різних органічно-мінеральних композицій.: біогенний композит, який $є$ продуктом анаеробного перетворення осадів стічних вод і фосфогіпсу; органічно-мінеральний компост на основі суміші фосфогіпсу, суперфосфату i гумусу великої рогатої худоби; та комбінацію суміші гумату натрію і суперфосфату. Була проведена інтеграція теоретичних і експериментальних принципів в синергетичний аналіз взаємозв'язків у системі «об'єкт - предмет дослідження» при вивченні динаміки змін форм знаходження важких металів у грунті. Відсотковий вміст мобільних форм важких металів, що виділяються екстрагентом від їх питового вмісту до і після обробки грунту органічно-мінеральними композиціями визначені 3 використанням спектрофотометричним методом. Здійснено порівняння ефективності обробки грунту. Використання методів математичної статистики дозволило довести кореляційний зв'язок між динамікою значень окислювальної здатності біомаси для біома грунту і швидкостю окислення субстрату для різного вмісту біокомпозиту.
\end{abstract}

Ключові слова: важкі метали, рекультивація грунта, органічно-мінеральні композиції, фосфогіпс, біом грунту, окислювальна здатність біомаси. 